\title{
Interfirm network structure and firm resources: Towards a unifying concept
}

\author{
Jesse Karjalainen ${ }^{1}$ (D, Aku Valtakoski ${ }^{2}$ iD, \\ Ilkka Kauranen ${ }^{3}$
}

\begin{abstract}
PURPOSE: The objective of this paper is to propose a concept of network resource distribution that systematically unifies the resource-based and network-based perspectives on interfirm networks and enables integrated analysis of how firm resources and network structure interact to affect firm performance. METHODOLOGY: This conceptual paper first reviews the extant literature on interfirm networks and then develops the unifying concept of network resource distribution. FINDINGS: The literature review indicates that strategy scholars have long sought to integrate the resource-based view and the social network explanations of firm performance but, thus far, only a partial integration has been achieved. In particular, studies on the resource-level heterogeneity of interfirm networks have largely been limited to the analysis of firm dyads. How firm resources and network structure beyond the immediate network partners interact to affect firm performance has not yet been adequately addressed. The proposed unified concept of network resource distribution systematizes prior research and illuminates how network structure and firm resources interact to affect firm performance beyond the immediate network partners. IMPLICATIONS FOR THEORY AND PRACTICE: For theory, this paper highlights gaps in the extant literature on interfirm networks and proposes a unifying concept that can be utilized to address these gaps and to develop further theory in the area. For practice, this paper encourages managers not to limit their analyses of strategic alliances to immediate partnerships; it is also crucial to consider the partners and their resources, and reflect on how they are related to one another outside of the immediate partnership portfolio. ORIGINALITY AND VALUE: Network resource distribution is a novel concept that ties together and systematizes various strands

\footnotetext{
1 Jesse Karjalainen, D.Sc. (Tech.), Researcher, Aalto University School of Science, Department of Industrial Engineering and Management, P.O. Box 11000, Fl-00076 Aalto, Finland, email: jesse.h.karjalainen@gmail.com (ORCID ID: https:// orcid.org/0000-0001-7446-4252).

2 Aku Valtakoski, Ph.D., Senior Lecturer, Linköping University, Department of Management and Engineering, SE-581 83 Linköping, Sweden, email: aku.valtakoski@liu.se (ORCID ID: https://orcid.org/0000-0003-4543-0015).

3 Ilkka Kauranen, D.Sc. (Tech.), Professor Emeritus, Aalto University School of Science, Department of Industrial
} Engineering and Management, P.O. Box 11000, FI-00076 Aalto, Finland, email: ilkka.kauranen@gmail.com
\end{abstract}


of research on interfirm networks, thus providing a foundation for future research in the area. The concept is also amenable to detailed operationalization, facilitating subsequent quantitative testing of theoretical arguments combining firm resources and the structure of a network.

Keywords: resource-based view, strategic networks, interorganizational relations, alliances, firm performance

\section{INTRODUCTION}

Strategy scholars have long attributed differences in firm performance to the internal characteristics of a firm, typically conceptualized as resources (Barney, 1991; Wernerfelt, 1984) or capabilities (Teece, Pisano, \& Shuen, 1997). Simultaneously, strategic network scholars have posited that superior firm performance is related to a firm's external network of interfirm ties (Dyer \& Singh, 1998; Gulati, 1998; Baum, Calabrese, \& Silverman, 2000; Gulati, Nohria, \& Zaheer, 2000). While both perspectives have been successful in explaining many aspects of firm performance, research on strategic management has also sought to integrate these two streams of research for a more nuanced and comprehensive understanding. Integrative studies have indicated, for example, that the capabilities of network partners influence the focal firm performance (Baum et al., 2000), that the network structure may enable firms to better leverage their internal capabilities for improved performance (Zaheer \& Bell, 2005), and that the configuration of alliance portfolios can affect the focal firm performance (Jiang, Tao, \& Santoro, 2010; Lavie, 2007; Lee, Kirkpatrick-Husk, \& Madhavan, 2017; Subramanian \& Soh, 2017; Wassmer, 2010). Although this integrated approach has provided a more holistic view of the sources of competitive advantage, there are still significant gaps in the understanding of how firm resources and interfirm networks interact to affect organizational performance (Burt \& Soda, 2021).

In particular, most of the integrative studies accounting for the resourcelevel heterogeneity of interfirm networks are limited to the analysis of firm dyads (Gulati, Lavie, \& Madhavan, 2011; Phelps, 2010; Phelps, Heidl, \& Wadhwa, 2012; Zaheer \& Bell, 2005). Studies spanning beyond the focal firm's immediate partners tend to aggregate network partner resources and thus ignore the potential influence of the actual location of resources within the network. The understanding of how the interfirm network structure interacts with the resources within the network is thus limited, particularly regarding the whole network level of analysis. In fact, recent empirical studies investigating interfirm and knowledge networks (e.g., Wang, Rodan, Fruin, \& Xu, 2014; Guan \& Liu, 2016) indicate that indirect ties matter and that the network position of a partner is often unrelated to what the partner has 
to offer in terms of resources. These studies thus suggest that aggregating network partner resources result in an incomplete understanding of interfirm networks, potentially biasing results. Consequently, there is a need to better reconcile the resource-based and network-based perspectives beyond the dyadic level of analysis. Although the practical challenge of collecting data on relationships among a large population of network actors is likely to have contributed to the scarcity of integrative research (Monaghan, Lavelle, \& Gunnigle, 2017; Schilling, 2009), it is also possible that this scarcity is due to the lack of appropriate conceptual tools for adequately accounting for both perspectives beyond the immediate partners.

The objective of this paper is to propose a concept of network resource distribution that systematically unifies the resource-based and network-based perspectives on interfirm networks and enables integrated analysis of how firm resources and network structure interact to affect firm performance. By introducing this novel concept, this paper contributes to research on interfirm networks in two ways. First, the concept ties together various strands of research on interfirm networks, thus facilitating the integration of the resource-based view and the social network theory, called for in prior research (Phelps et al., 2012), and provides a systematic foundation for future research in the area. Second, similar to the work of Carpenter, Li, and Jiang (2012), this concept supports a systematic method of operationalizing the complex combination of network structure and resources, further facilitating subsequent quantitative testing of theoretical arguments combining firm resources and interfirm network structure.

The paper is organized as follows. First, a brief review of the literature using the resourced-based view to study interfirm networks is presented, followed by a similar review of studies utilizing the social network theory and studies that combine the two theoretical perspectives. Building upon the review, the unifying concept of network resource distribution is introduced and elaborated. Then, a formal definition of the concept is provided to facilitate its use in strategy research. Next, five previous papers combining the resource-based view and network theory are discussed, and their relation to the concept is elaborated. Discussion on the significance and potential uses of the concept concludes the paper. 


\section{LITERATURE OVERVIEW}

\section{The resource-based view and interfirm networks}

The resource-based view posits that competitive advantage and, consequently, firm performance variance can be explained by analyzing the internal resources of firms (Barney, 1991; Peteraf, 1993; Wernerfelt, 1984). Resources are typically defined in a very broad manner, encompassing physical, knowledge, and cultural aspects of a firm. The resource-based view argues that firm performance differences are attributable to unique and valuable resources (Barney, 1991), competences (Prahalad \& Hamel, 1990) or capabilities (Teece et al., 1997) around which firms devise value-creating strategies that allow them to accrue above-average profits (Lavie, 2006; Peteraf, 1993).

The resource-based view has also been applied to the analysis of interfirm networks. From the resource-based perspective, the main rationale for firms to engage in interfirm relationships is to gain access to valuable complementary resources (Das \& Teng, 2000; Eisenhardt \& Schoonhoven, 1996; Lado, Boyd, \& Hanlon 1997; Madhok \& Tallman 1998), including knowledge accessed through interfirm learning (e.g., Lin, Wu, Chang, Wang, \& Lee, 2012; Subramanian, Bo, \& Kah-Hin, 2018). Partners' complementary resources enable firms to pursue opportunities that would otherwise either be unavailable due to lack of resources or unfeasible due to the expenses of developing and integrating resources internally. Interfirm alliances help the focal firm access complementary resources while maintaining a focus on the development and exploitation of its core competencies (Wassmer, Li, \& Madhok, 2017). Access to complementary resources may also constitute a necessary condition for appropriating returns from the firm's own resources (Teece, 1986; Carnabuci \& Operti, 2013).

In addition, as argued by Dyer and Singh (1998), the resource combinations created from the resources of two firms may be so unique in themselves that the interfirm relationship itself may constitute a source of competitive advantage (Galunic \& Rodan, 1998; Mesquita, Anand, \& Brush, 2008; Wang \& Zajac, 2007). Lavie (2006) developed this notion further by proposing an integrated theoretical model of competitive advantages arising from interfirm collaboration. In Lavie's model, competitive advantage from interfirm collaboration derives from three types of rents: internal rents, resulting from the use of the focal firm's internal resources; appropriated relational rents, derived from the use of shared resources; and spillover rents, generated by the partner's resources. Together, these prior studies indicate that resource sharing in interfirm alliances can yield significant competitive advantages and that network partners and their resources can 
affect the performance of the focal firm both directly through relational rents and indirectly through spillover rents.

Furthermore, the relationships of the focal firm and the resources residing in the interfirm network may also be considered to constitute network resources (Gulati, 1999, 2007; Gulati, Lavie \& Madhavan, 2011; Huggins 2010) or social capital (Dyer \& Hatch, 2006; Inkpen \& Tsang, 2005; Koka \& Prescott, 2002; Tsai \& Ghoshal, 1998; Walker, Kogut, \& Shan 1997), both of which might be valuable to the focal firm.

In short, the resource-based view suggests that competitive advantage in interfirm networks and interfirm relationships stems from (1) access to valuable complementary resources that allow the focal firm to concentrate on its core activities and to appropriate returns from its own resources; (2) unique and hard-to-imitate resource combinations created through collaboration between two or more firms; and (3) the interfirm network itself as a valuable resource for the focal firm, as suggested by the social capital concept.

While these resource-based explanations of the impact of interfirm networks have advanced understanding on how external resources affect the performance of the focal firm, prior studies have largely been limited to firm dyads; less is known about how the resources of the entire interfirm network influence the focal firm performance (Gulati et al., 2011; Phelps, 2010; Phelps et al., 2012; Powell, Koput, \& Smith-Doerr, 1996; Shan, Walker, \& Kogut, 1994; Zaheer \& Bell, 2005). For example, research on alliance portfolios has extended attention from a purely dyadic level of analysis to consideration of all immediate partners of the focal firm (Cui \& O'Connor, 2012; Hagedoorn, Lokshin, \& Zobel, 2018; Jiang et al., 2010; Lavie, 2007; Lee et al., 2017; Subramanian \& Soh, 2017; Wassmer, 2010; Wuyts \& Dutta, 2014). Yet, ignoring the impact of alliance network partner characteristics beyond the immediate partners may result in a limited and potentially skewed view of how these more distant partners and their resources affect the performance of the focal firm. The focal firm may thus become too preoccupied with its immediate partners to consider how they should be positioned vis-à-vis other firms in the network. For example, the focus on immediate partners may distract attention from valuable complementary knowledge resources possessed by more distant firms in the interfirm network (Hansen, 2002). Intermediaries may be required to access and translate the required knowledge so it can be absorbed by the focal firm (Howells, 2006; Shohet \& Prevezer, 1996). These intermediaries may become congested if multiple firms try to access partner resources through them (Aggarwal, 2020). In conclusion, the resource-based view of interfirm networks lacks a coherent theoretical explanation of when the resources of indirectly related network partners matter for the focal firm performance. 


\section{The social network theory and interfirm networks}

The social network theory posits that firms are always embedded in social networks built on various relationships among firms, ranging from informal relationships among management to formal licensing and joint venture agreements (Zaheer, Gözübüyük, \& Milanov, 2010). Network embeddedness both enables and restricts the strategic actions of the focal firm (Gargiulo \& Benassi, 2000; Polidoro, Ahuja, \& Mitchell, 2011; Uzzi, 1997). Unlike the resource-based view, which emphasizes the rational choice of partners based on resource complementarity and similarity, the influence of network embeddedness is more holistic; it depends on the overall interaction with other firms and considers the network both as an antecedent to the focal firm performance and a consequence of firm partnering decisions (Borgatti \& Halgin, 2011). The social network theory suggests that superior firm performance is due to the position of the focal firm within the interfirm network (Burt, 2000; Inkpen \& Tsang, 2005; Stuart, 1998; Zaheer \& Bell, 2005) and overall network structure (Gilsing, Nooteboom, Vanhaverbeke, Duysters, \& van den Oord, 2008; Schilling \& Phelps, 2007; Soh, 2010).

Prior literature suggests that networks enhance the competitive advantage of a firm through three mechanisms. First, social networks function as conduits of knowledge and can relay valuable information efficiently and in a timely fashion. As argued by Burt (2004), firms that occupy a central position in a network are likely to have a superior position and positional advantage in terms of negotiating power, access to information, and brokering. Second, an interfirm network may have structural holes (Burt, 1992), defined as the lack of direct ties between specific firms in the network. Structural holes present opportunities for explorative learning (Uzzi, 1996) brokerage (Burt \& Soda, 2021; Kwon, Rondi, Levin, De Massis, \& Brass, 2020), and the creation of novel resource combinations (Nahapiet \& Ghoshal, 1998; Tsai $\&$ Ghoshal, 1998). These mechanisms enhance the focal firm performance (Zaheer \& Bell, 2005b). Third, networks are argued to be superior to other forms of governance when firms are adapting to new conditions in the competitive environment (Dittrich \& Duysters, 2007; Kraatz, 1998). Given efficient transmission of knowledge about changes in the environment, and high flexibility resulting due to lack of rigid governance structures, interfirm networks can facilitate a swift strategic response to environmental changes, again improving firm performance.

While the existing social network theory literature suggests that interfirm ties and embeddedness in interfirm networks affect firm performance, most prior studies have only considered the impact of network structure; only a limited number of studies have explored the interplay between network 
structure and the actual resources present in the network (cf. Phelps et al., 2012). Most studies have implicitly assumed that network structure in itself explains firm performance sufficiently well. Yet, as discussed in relation to the resource-based view, firm resources, network partner resources, and how they are related to one another, do influence firm performance (Gulati et al., 2011). Hence, differences in firm performance are thus likely to depend not only on the structure of the interfirm network they are embedded in but also on how resources are distributed within the network. Recent empirical studies that investigate interfirm networks by decomposing firms into resource-level knowledge components support this view (Wang et al., 2014; Guan \& Liu, 2016). These studies indicate that indirect ties matter and that the network position does not necessarily imply what resources the partner has, suggesting that resource-level disaggregation of firms on the whole network level is required to understand fully how embeddedness affects the focal firm performance.

\section{Integration of the resource-based view and the social network theory}

The resource-based view and the social network theory explanations of interfirm networks are interrelated. Accessing the resources of a partner requires an interfirm relationship, which consequently embeds the focal firm in a social network. Conversely, being embedded in a social network can be considered a resource in itself. However, research combining the two perspectives is still limited (Burt \& Soda, 2021), and how exactly the two theoretical perspectives interact to influence the focal firm performance and how this interaction should be conceptualized remains unclear.

To understand further how exactly the resource-based view and the social network theory have been combined in prior research, a literature review was conducted. Articles were searched in citation databases, such as Web of Science and Google Scholar, by using relevant keywords such as "resourcebased," "networks," "embeddedness," "social capital," "organizational," "firm," "interfirm," "ties," "collaboration," and "alliances." Initially, articles were included or excluded based on their title. For each tentatively included article, the abstract and, ultimately, the full text were inspected to check if the article fitted two sampling criteria. First, only articles that explicitly (i.e., in hypotheses) combined both perspectives were included. Second, only papers addressing firm-level effects were included. Articles meeting these criteria were then categorized with respect to two dimensions: the level of network structure and the scope of resources addressed in the article.

First, the categorization of the level of network structure used three possible levels of analysis: the dyadic level, the ego network level, and the 
whole network level. The dyadic level, or ego network with distance 1 , includes only the direct ties and the related immediate partners of the focal firm (the "ego"). Typical measures related to the dyadic level of networks are the number of ties and the strength of ties. The ego network level refers to ego networks with unlimited distance and differs from the dyadic level by fully accounting for all possible network partners, including those only indirectly related to the focal firm. Since the number of articles studying entire ego networks was very small, no typical measures of network structure used on this level could be inferred. However, based on the social network theory, potential measures for ego network level analysis include path length (the number of ties needed to reach from the focal firm to another) and the number of indirect ties (the number of firms accessible through immediate partners). The whole network level includes all firms and all possible ties within an interfirm network. Two types of measures of whole network structure were identified (c.f., Carpenter et al., 2012). The first type of measure considers the overall structure of the network (thus independent of the focal firm) and includes measures such as network density, the number of structural holes, and cohesion. The second type of measure characterizes the focal firm's position within the whole network and includes measures such as betweenness and centrality.

Second, the articles were categorized into three distinct types of resource scope depending on which firms' resources were included in the theoretical models. The first type of articles included only the focal firm's resources in the interaction between resources and network structure. The second type included the resources of both the focal firm and its network partners. The final type of articles included only the resources of network partners.

These categorizations resulted in a 3-by-3 matrix of studies, summarized in Table 1. Next, each cell of the matrix and the limitations of extant studies in terms of understanding the interaction between resources and network structure are discussed. 
Table 1. Studies integrating the resource-based view and the social network theory

\begin{tabular}{|c|c|c|c|}
\hline \multirow{2}{*}{$\begin{array}{l}\text { Network } \\
\text { structure level }\end{array}$} & \multicolumn{3}{|c|}{ Resources } \\
\hline & Focal firm & Both & Partners \\
\hline $\begin{array}{l}\text { Dyadic } \\
\text { Measures: } \\
\text { Tie existence } \\
\text { Tie strength } \\
\text { Number of ties }\end{array}$ & $\begin{array}{l}\text { How do the resources } \\
\text { of the focal firm } \\
\text { affect the impact of } \\
\text { immediate ties? } \\
\text { Examples: Anand and } \\
\text { Khanna (2000) } \\
\text { Eisenhardt and } \\
\text { Schoonhoven (1996) } \\
\text { Lee et al. (2001) } \\
\text { Powell et al. (1996) } \\
\text { Uzzi and Lancaster } \\
\text { (2003) } \\
\text { Walker et al. (1997) }\end{array}$ & $\begin{array}{l}\text { How do the resources } \\
\text { of the focal firm and } \\
\text { immediate partners } \\
\text { interact with the } \\
\text { immediate ties? } \\
\text { Examples: Das et al. } \\
\text { (1998) } \\
\text { Inkpen (2000) } \\
\text { Inkpen and Tsang } \\
\text { (2005) } \\
\text { Gulati (1999) } \\
\text { Reagans and McEvily } \\
\text { (2003) } \\
\text { Lin et al. (2009) } \\
\text { Vasudeva et al. (2013) } \\
\text { Subramanian and Soh } \\
\text { (2017) }\end{array}$ & $\begin{array}{l}\text { How do the resources } \\
\text { possessed by immediate } \\
\text { partners affect the focal } \\
\text { firm performance? } \\
\text { Examples: Gulati and } \\
\text { Higgins (2003) } \\
\text { Koka and Prescott (2002) } \\
\text { McEvily and Marcus } \\
\text { (2005) }\end{array}$ \\
\hline $\begin{array}{l}\text { Ego } \\
\text { Measures: } \\
\text { Path length } \\
\text { Indirect ties }\end{array}$ & $\begin{array}{l}\text { How do focal firm } \\
\text { resources interact } \\
\text { with local network } \\
\text { structure beyond the } \\
\text { dyadic level? }\end{array}$ & $\begin{array}{l}\text { How do focal firm } \\
\text { resources and } \\
\text { resources of more } \\
\text { distant partners } \\
\text { affect the focal firm } \\
\text { performance? } \\
\text { Example: Gulati } \\
\text { (1995a) }\end{array}$ & $\begin{array}{l}\text { How do the resources } \\
\text { of partners beyond } \\
\text { the immediate ones } \\
\text { affect the focal firm } \\
\text { performance? }\end{array}$ \\
\hline $\begin{array}{l}\text { Whole } \\
\text { Measures: } \\
\text { Centrality } \\
\text { Connectedness } \\
\text { Structural holes }\end{array}$ & $\begin{array}{l}\text { How do focal firm } \\
\text { resources affect the } \\
\text { impact of overall } \\
\text { network structure } \\
\text { and position? } \\
\text { Examples: Tsai and } \\
\text { Ghoshal (1998) } \\
\text { Tsai (2001) } \\
\text { Guan and Liu (2016) }\end{array}$ & $\begin{array}{l}\text { How do focal firm } \\
\text { resources and } \\
\text { network resources } \\
\text { interact with the } \\
\text { network structure? } \\
\text { Examples: Arya and } \\
\text { Lin (2007) } \\
\text { Zaheer and Bell (2005) }\end{array}$ & $\begin{array}{l}\text { How do the resources } \\
\text { within the network } \\
\text { interact with the network } \\
\text { structure? } \\
\text { Examples: Bae and } \\
\text { Gargiulo (2004) } \\
\text { Owen-Smith and Powell } \\
\text { (2004) } \\
\text { Whittington et al. (2009) } \\
\text { Rulke and Galaskiewicz } \\
\text { (2000) }\end{array}$ \\
\hline
\end{tabular}

\section{Dyadic level studies}

One of the most common types of integrative studies focuses on the interaction between the focal firm's resources and its dyadic ego network structure. Typical focal firm resources considered include absorptive capacity 
(Dyer \& Singh, 1998; Tsai, 2001) and alliance capability (Kale, Dyer, \& Singh, 2002; Rothaermel \& Deeds, 2006). These studies seek to explain how the focal firm's capabilities and resources help the firm leverage the information and opportunities emerging in its dyadic network. An obvious shortcoming of these studies is that they ignore the resources of network partners, making it uncertain whether the partners actually possess resources valuable to the focal firm. These studies thus depend solely on the social network explanation of interfirm networks - the internal resources are merely factors that moderate the relationship between the dyadic network structure and the focal firm performance.

By contrast, dyadic level studies that incorporate the resources of the focal firm's immediate partners avoid this issue. By focusing on the fit between the focal firm's and its partners' resources, these studies explain the focal firm's performance through either resource complementarities (Kale, Singh, \& Perlmutter, 2000; Rothaermel \& Boeker, 2008) or similarities (Grant \& Baden-Fuller, 2004; Mowery, Oxley, \& Silverman, 1996). The first type of fit is based on the creation of unique complementary combinations of resources (Dyer \& Singh, 1998; Galunic \& Rodan, 1998; Wang \& Zajac, 2007; Wiklund \& Shepherd, 2008), while the second type of fit is based on the absorptive capacity arguments of having sufficient similarity for knowledge absorption (Cohen \& Levinthal, 1990; Lane \& Lubatkin, 1998). Typical resources considered in these studies include knowledge domains (Grant \& BadenFuller, 2004), technologies (Wang \& Zajac, 2007), organizational structures (Lane \& Lubatkin, 1998), and organizational culture (Gulati, 1995b; Inkpen \& Tsang, 2005). The focal firm's and partners' resources are not always treated symmetrically (Gulati, 1999; Inkpen, 2000; Stuart, 2000); the focal firm's resources are usually treated similarly to the first case of studies, while the network partners' resources are now assessed explicitly, or refer to partners' attitudes towards the focal firm (Simonin, 2004). Although these studies provide a more thorough explanation of interaction between firm resources and network structure than those based only on the focal firm's resources, they are still limited to the dyadic level network of the focal firm and disregard the potential effects of indirectly related firms and the whole network structure on firm performance.

Dyadic level studies that address the interaction between resources of the focal firm's immediate partners and the dyadic network structure are less common than the first two types discussed above. These studies typically analyze how the focal firm can leverage its dyadic network ties to benefit from the resources of its immediate partners. Partner resources considered include technological knowledge (Koka \& Prescott, 2002; Phelps, 2010), organizational prestige (Gulati \& Higgins, 2003), and organizational factors 
(McEvily \& Marcus, 2005). Although these studies improve on the first kind of study by considering which valuable resources the focal firm can access within its ego network they are still limited in three ways. First, the analysis still only considers the dyadic relationships with immediate partners. As discussed above, indirectly connected firms can also influence how the resources of these immediate partners impact the focal firm's performance. Second, with the exceptions of Koka and Prescott (2002) and Phelps (2010), partners are conceptualized as a homogeneous group that can be analyzed through simple resource aggregation. Yet, as suggested by Gulati and Higgins (2003), McEvily and Marcus (2005), and Phelps (2010), partners are likely to be dissimilar. Subsequently, the diversity of partners, and how they are managed, has an impact on the focal firm performance (Jiang et al., 2010). Third, the exclusion of the focal firm's resources raises the question of how well they are actually complemented by the resources of network partners.

\section{Ego network level studies}

There were extremely few examples of research on the ego network level that combined the analysis of firm resources and network structure. One rare example is Gulati's study of alliance formation in a social structure of interconnected firms (Gulati, 1995a). This study also considers the match between the focal firm's resources and network partners' resources in terms of strategic independence, referring to the usefulness of the partners' resources to the focal firm. It can thus be concluded that the understanding of the impact of resources embedded in interfirm networks, when accessed through indirect ties in an ego network setting, is severely limited.

\section{Whole network level studies}

Multiple studies analyzing the interaction between resources in interfirm networks and the whole network structure were found. These studies are in many ways similar to the studies discussing the interaction between resources and dyadic network structure. The whole network level studies are focused on how the focal firm's resources can be used to leverage the potential benefits of the whole network structure (Tsai, 2001; Tsai \& Ghoshal, 1998). However, rather than taking advantage of direct dyadic ties, here the focal firm benefits from the overall network structure or its position within the network. Resources of the focal firm considered in the research include absorptive capacity (Tsai, 2001) and trustworthiness (Tsai \& Ghoshal, 1998). Furthermore, Guan and Liu (2016) investigated both interfirm networks and resource-level knowledge networks, claiming that innovations are doubly 
embedded in these networks. Although Guan and Liu did not directly address the interaction between the interfirm network structure and resources in their analyses, they nevertheless provided evidence for the integrative perspective that indirect ties of interfirm networks do matter and that the network position of a partner does not necessarily imply what resources the partner possesses. Taken together, however, these studies are limited in the same sense as the dyadic level network studies - most studies disregard partners' resources and do not consider whether they are actually beneficial to the focal firm. For example, while the network structure may enhance access to knowledge or other specific resources, these resources may in fact be worthless to the focal firm.

Only a handful of studies discussing the interaction between the whole network structure and the resources of both the focal firm and its network partners were found. Zaheer and Bell's (2005b) study of interactions between firm capabilities and network position considered how the fit between the focal firm's capabilities and the aggregated capabilities of its network partners interacts with overall network structure. Arya and Lin (2007) studied the interaction between organizational characteristics, partner attributes, and network structure in a not-for-profit context. These studies are more enlightening than the previous type of studies. By considering how the focal firm should be positioned in relation to the resources of its partners, these studies provide a more detailed view of how exactly the network structure benefits the focal firm, given the resources of the network partners. However, these studies present an additional challenge: if the partners' resources are aggregated at the whole network level, information on the exact location of these resources is lost, precluding analysis of how individual partners' resource endowments affect the focal firm performance.

The whole network level studies discussing the interaction between the global network structure and the resources of network partners explore how the whole network structure should be matched with aggregated partner resources. Specific partner resources considered include organizational prestige (Kraatz, 1998), controlled resources (Bae \& Gargiulo, 2004), and organization type (Owen-Smith \& Powell, 2004). However, these studies forgo the analysis of the precise ego network structure required to leverage these resources. More specifically, these studies do not analyze where exactly the resources are located within the network and instead assume that the focal firm can access them somewhere in the network. In addition, similar to the dyadic network level, excluding a focal firm's resources from the analysis introduces the problem of not knowing whether there is in fact a fit between the resources of the focal firm and those of its partners. 


\section{THE UNIFYING CONCEPT OF NETWORK RESOURCE DISTRIBUTION}

The brief review of literature that integrates the resource-based view and the social network theory indicates that while much is known about how resources and network structures interact to affect the focal firm performance on the dyadic level, the understanding of how resources and network structures interact to affect the focal firm performance on the ego and whole network levels is limited. In particular, it is poorly understood how the detailed resource structure of an interfirm network beyond the dyadic level is related to firm performance. It is contended that the understanding of the impact of interfirm networks on firm performance can be improved by introducing a concept that transcends existing conceptualizations of the interaction between resources and network structure and that provides a coherent new framework for integrating existing research. To this end, this paper proposes the unifying concept of network resource distribution that facilitates a detailed analysis of how firm resources and interfirm network structure interact to affect the focal firm performance.

Network resource distribution is defined as a spatial pattern of resources within an interfirm network in which a specific location is related to specific levels of those resources. The concept thus explicitly combines network structure and firm resources and crucially incorporates information on what resources firms possess with the information on where these resources are located within the interfirm network. Network resource distributions are agnostic with respect to the type of ties between firms, and can be based on any type of relationship, including formal alliance agreements or informal collaboration. Similar to the resource-based view, firms are conceptualized as bundles of resources. The network of firms can thus be construed as a network of resources localized at the interfirm network nodes that represent firms. Each resource has a particular level at each node (i.e., firm) of the interfirm network, resulting in a particular pattern of resources distributed throughout the network. To simplify the discussion, it is assumed that the network consists of a single connected group of firms instead of multiple disconnected groups of firms.

An example of an interfirm network with two resources-resource $A$ and resource $B-i s$ shown in Figure 1 . The levels of the two resources vary throughout the network. There are thus two types of knowledge regarding this interfirm network: (1) the level of resources located at each node of the network and (2) the ties (i.e., relationships) between the nodes. The network of interfirm ties combined with the resources of the firms constitute a network resource distribution - a unique pattern of resource levels and how they are related to each other. 


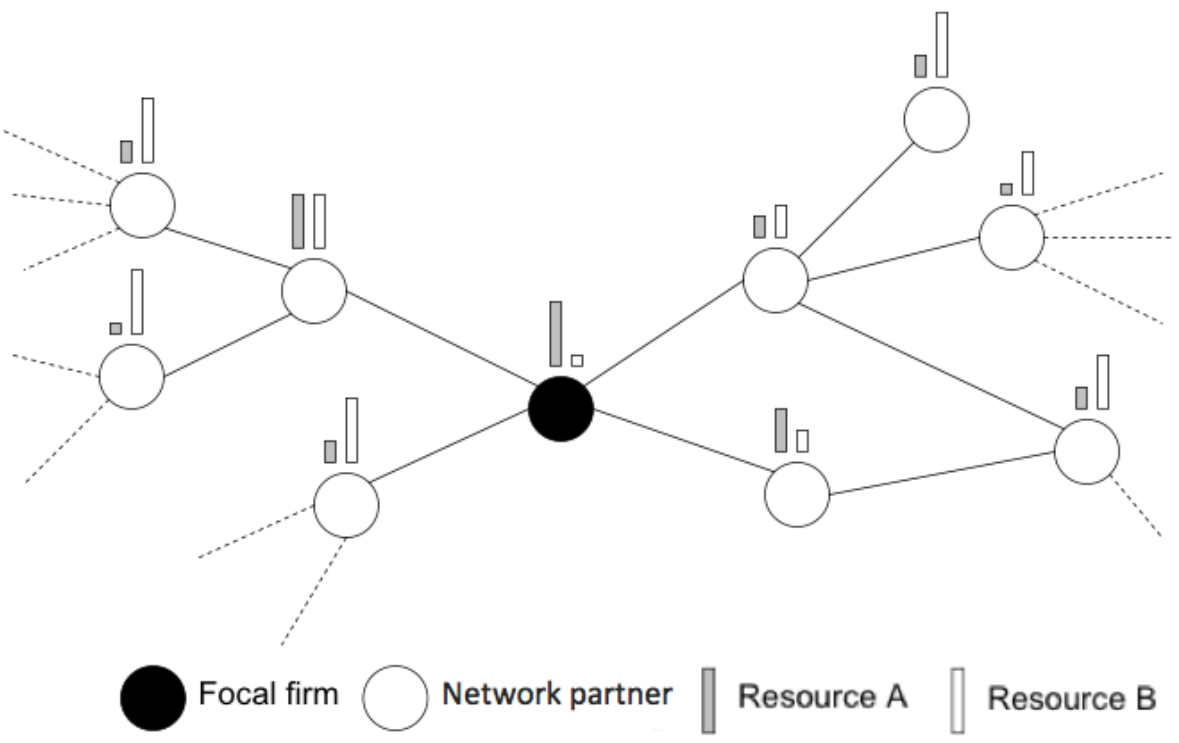

In the above figure, the focal firm and each network partner are network nodes. Solid lines depict connections between the network nodes. Dashed lines depict connections to network nodes not visible in the figure. The pillars above a node indicate the types and levels of resources localized at that network node. The resource type is indicated by the pillar color, and the resource level (i.e., how much of that resource resides at the given node) is indicated by the pillar height.

Figure 1. An example of varying resource levels in an interfirm network

The network resource distribution is a generic abstract concept. Because interfirm networks are typically characterized by a complex structure, marked by a large number and variety of interfirm ties and by nodes composed of a large number of heterogeneous firms, each having a certain set of resources and a certain level of each resource, the related specific network resource distributions remain somewhat elusive. Hence, to operationalize the concept in order to test hypotheses regarding the interplay between firm resources and network structure, one needs to decide which precise structural and resource aspects of the network one wants to analyze (cf. Carpenter et al., 2012). Specifically, first, to reduce the complexity related to the network structure, one needs to choose what type of network structural metric would be relevant to the research question at hand. Next, to reduce the complexity related to the resources, one must define what specific resource metric would best serve the objective of the study.

A network resource distribution can accommodate multiple types of relationships between firms simultaneously. Above, only the spatial pattern of 
ties between firms was used to determine the network resource distribution. However, the concept can also incorporate tie strength in terms of, for example, trust and the frequency of interaction between firms, which have been shown to have an impact on interfirm networks and, subsequently, on firm performance (Gulati, 1995b; Krishnan, Martin, \& Noorderhaven, 2006).

Moreover, a network resource distribution can also accommodate any number of resources or even a continuum of resource types. The specific operationalization of the concept can be based on one or more resources, depending on the research question at hand. In some cases, several distinct operationalizations of the concept could be used simultaneously, one for each resource of interest in order to examine their interactions, for example.

\section{Formal definition of a network resource distribution}

To illustrate how a network resource distribution can be operationalized and applied in empirical research, it may be formally defined as follows. First, an interfirm network can be represented as an $\mathrm{N} \times \mathrm{N}$ matrix that indicates the existence of ties between firms. In the simplest case, this may be represented as either 0 -no tie exists between the two firms-or 1-some kind of tie exists between the two firms. This approach can be generalized in the sense that this structure can also incorporate tie strength, indicated by the magnitude of the linkage in the matrix, as well as tie directionality-ties do not need to be reciprocal. This network structure matrix can be used to describe a very broad range of network relationships.

Each resource within the interfirm network can be represented by an $\mathrm{N}$-dimensional vector $\mathrm{r}=\mathrm{r}(\mathrm{i})$, where the value of one component indicates the level of the resource possessed by a particular firm i within the network. Like the network structure matrix, these resource vectors can accommodate a wide variety of resource distributions, ranging from monopolized resources-value 1 for one firm and 0 for all others - to different types of knowledge with no sharp differences in the level of knowledge between firms. All observed resource levels within the network, in turn, can be represented by an $\mathrm{N} \times \mathrm{M}$ resource matrix, where $\mathrm{M}$ is the number of resource vectors (i.e., distinct resources).

As indicated above, various network metrics calculated from the network structure matrix are used to facilitate a closer analysis of the network structure. Choosing a focal firm-or "ego firm" - for analysis, these metrics can be expressed as $m=m(i, j)$, where $i$ and $j$ denote firms within the network. There are two main types of network metrics: (1) structural metrics and (2) distance metrics. 
Structural metrics, such as betweenness centrality and number of structural holes, describe the overall structure of the network. Some structural metrics, such as the number of structural holes, are calculated for the whole network, and do not depend on the focal firm. In this case the value of a structural metric is the same for all firms in the network. Other structural metrics, such as betweenness centrality, depend on the chosen focal firm. Structural measures can be calculated either for the whole network or for the immediate ego network.

Distance metrics describe how distant two firms are from each other within the interfirm network. The value of a distance metric, such as path length, thus depends on the choice of two firms; it is a function of both the focal firm and the chosen alter in the network. For example, the path length metric indicates how many ties are needed to connect the focal firm to the chosen alter.

Depending on which network structure metric is used the resultant metric is (1) constant for all firms, (2) dependent on the chosen focal firm, or (3) dependent on both the chosen focal firm and another firm. The resultant network resource distribution can thus have zero, one, or two dimensions, respectively. The zero-dimensional network resource distribution relates the resources available in the whole network to the whole network structure by using a network structure metric that is independent of the focal firm. Because the network metric in this case reduces to a constant, the resulting network resource distribution is zero-dimensional with respect to the network structure. However, there is still a two-dimensional resource matrix with $M$ resource endowment vectors, each with $\mathrm{N}$ components corresponding to the firms within the network. The complexity of the resource matrix can be reduced, for example, by calculating the aggregate level of one resource-by summing over all eligible nodes for one resource-or the variance of resources-by calculating the variance of resources over multiple resources and all nodes. In either case, the result is a single measure that describes the resources within the network. This figure can then be multiplied by the network structure metric, yielding a zero-dimensional network resource distribution.

The one-dimensional network resource distribution relates the resources within the network to the network structure and it can be applied on both ego and whole network levels. In both cases, the network structural metric depends on the chosen focal firm and is thus one-dimensional. As in the previous zero-dimensional case, there is still a need to reduce the complexity of the resource matrix by aggregating one resource or calculating the variety of resources, for example. Multiplying the resource metric and the network structure metric, results in a one-dimensional network resource distribution that depends on the choice of the focal firm. 
The two-dimensional network resource distribution relates the resources available within the whole network to the distance between the focal firm and the network partners. In this case the network metric depends not only on the focal firm but also on the particular alter and is thus two-dimensional. Combining the network structure matrix with the resource matrix yields a two-dimensional network resource distribution for each observed resource. Formally, there is a function $d(i, j)$ for each pair of firms that describes the level of resources at firm $j$ as measured from firm $i$. The focal firm can also be included in the formulation as the value for $d(i, i)$. Obviously, this is the most general and complex description of the interaction between firm resources and the network structure. This formulation can be applied to the whole network or to a subset of the network. For example, a researcher may limit the analysis to only the closest network partners (i.e., the dyadic level). Effectively, this means setting a threshold for the used metric. As an example, a two-dimensional network resource distribution can be used to describe the degree of access the firms in the network have to certain types of knowledge held by other firms in the network. In this case, the network structure metric could be based on inverse values of path lengths (Hansen, 2002), which could then be interacted with the levels of knowledge held by the firms to correct for the loss of value that might occur when the knowledge has to be indirectly accessed to form the two-dimensional network resource distribution. To use the distribution in quantitative analysis, one could calculate the sum of distance-corrected knowledge level values for each firm and correlate them with the firm performance measures, for example.

A summary of the above formulations of specific network resource distributions is given in Table 2. To summarize, to operationalize the concept of network resource distribution, the interfirm network structure and firm resources are first modeled as a network structure matrix and a resource matrix, respectively. Then, in most cases, the complexity related to both matrixes is reduced by choosing specific metrics for them. Finally, the network structure metric is interacted with the resource metric to arrive at a specific network resource distribution. The resulting network resource distributions describe how a particular resource or resources are distributed throughout the entire network as seen from the perspective of the focal firm. This distribution can then be incorporated in an analysis of outcomes of interest, such as the focal firm performance. 
Table 2. Network resource distribution types

\begin{tabular}{|c|c|c|c|}
\hline $\begin{array}{l}\text { Network resource } \\
\text { distribution type }\end{array}$ & Network level & $\begin{array}{l}\text { Examples of } \\
\text { network metrics }\end{array}$ & $\begin{array}{l}\text { Examples of resource } \\
\text { measures }\end{array}$ \\
\hline $\begin{array}{l}\text { Zero-dimensional } \\
\mathrm{d}=\mathrm{m} * \mathrm{r}\end{array}$ & Whole network & $\begin{array}{l}\text { Number of } \\
\text { structural holes } \\
\text { Cohesion }\end{array}$ & $\begin{array}{l}\text { Aggregation of one resource } \\
\text { Variety over multiple resources }\end{array}$ \\
\hline $\begin{array}{l}\text { One-dimensional } \\
\mathrm{d}(\mathrm{i})=\mathrm{m}(\mathrm{i}) * \mathrm{r}(\mathrm{i})\end{array}$ & $\begin{array}{l}\text { Ego networks } \\
\text { Whole network }\end{array}$ & $\begin{array}{l}\text { Betweenness } \\
\text { Degree } \\
\text { Closeness } \\
\text { Clustering } \\
\text { coefficient } \\
\text { Access to bridging } \\
\text { ties }\end{array}$ & $\begin{array}{l}\text { Aggregation of one resource } \\
\text { Variety over multiple resources }\end{array}$ \\
\hline $\begin{array}{l}\text { Two-dimensional } \\
d(\mathrm{i}, \mathrm{j})=\mathrm{m}(\mathrm{i}, \mathrm{j}) * r(\mathrm{j})\end{array}$ & $\begin{array}{l}\text { Whole network } \\
\text { Ego networks }\end{array}$ & $\begin{array}{l}\text { Path length } \\
\text { Cluster membership }\end{array}$ & $\begin{array}{l}\text { One type of resource, no } \\
\text { aggregation }\end{array}$ \\
\hline
\end{tabular}

The above functions of $d, m$, and $r$ stand for network resource distribution, network structure matrix, and resource matrix, respectively. The parameters $\mathrm{i}$ and $\mathrm{j}$ depict firms in the network.

\section{Relating network resource distribution to existing integrative research}

To illustrate how the generic network resource distribution concept is related to prior research integrating network structure and resources, five selected studies that have combined the resource-based view and the social network theory, shown in Table 3, are analyzed and discussed in detail. This demonstrates how the concept can be applied in practice.

\section{Baum et al. (2000)}

The seminal study by Baum et al. (2000) analyzed the impact of alliance network composition on start-up performance in the context of biotechnology firms. Their study related alliance network size and efficiency, defined in terms of diversity of partner types, with the innovative capabilities and relative competitive scopes of potential partners. 
Table 3. Relating the concept of network resource distribution to select studies

\begin{tabular}{|c|c|c|c|c|}
\hline Study & $\begin{array}{l}\text { Network } \\
\text { level }\end{array}$ & $\begin{array}{l}\text { Distribution } \\
\text { type }\end{array}$ & $\begin{array}{l}\text { Network } \\
\text { metrics }\end{array}$ & Resource metrics \\
\hline $\begin{array}{l}\text { Baum et al. } \\
(2000)\end{array}$ & Ego network & $\begin{array}{l}\text { One- } \\
\text { dimensional }\end{array}$ & $\begin{array}{l}\text { Network } \\
\text { efficiency } \\
\text { Network size }\end{array}$ & $\begin{array}{l}\text { Relative market } \\
\text { scope of partners } \\
\text { Partner } \\
\text { innovativeness }\end{array}$ \\
\hline $\begin{array}{l}\text { Bae and } \\
\text { Gargiulo (2004) }\end{array}$ & $\begin{array}{l}\text { Ego network, } \\
\text { with ties } \\
\text { between } \\
\text { partners }\end{array}$ & $\begin{array}{l}\text { One- } \\
\text { dimensional }\end{array}$ & Network density & $\begin{array}{l}\text { Aggregate market } \\
\text { power of partners } \\
\text { Share of critical } \\
\text { partners }\end{array}$ \\
\hline $\begin{array}{l}\text { Koka and } \\
\text { Prescott (2008) }\end{array}$ & $\begin{array}{l}\text { Whole } \\
\text { network }\end{array}$ & $\begin{array}{l}\text { One- } \\
\text { dimensional }\end{array}$ & $\begin{array}{l}\text { Eigenvector } \\
\text { centrality } \\
\text { Structural holes } \\
\text { Number of ties }\end{array}$ & Ego strategy \\
\hline \multicolumn{4}{|c|}{$\begin{array}{l}\text { Zaheer and Bell (2005) } \\
\text { Whole network } \\
\text { One-dimensional } \\
\text { Structural holes }\end{array}$} & $\begin{array}{l}\text { Ego innovativeness } \\
\text { Average } \\
\text { over partner } \\
\text { innovativeness }\end{array}$ \\
\hline Phelps (2010) & $\begin{array}{l}\text { Ego network, } \\
\text { with ties } \\
\text { between } \\
\text { partners }\end{array}$ & $\begin{array}{l}\text { One- } \\
\text { dimensional }\end{array}$ & Network density & $\begin{array}{l}\text { Technological } \\
\text { diversity }\end{array}$ \\
\hline
\end{tabular}

Expressed in terms of the network resource distribution concept, the study by Baum et al. (2000) is an example of a one-dimensional network resource distribution in which the network metric is calculated for the ego network of each firm. Baum et al. (2000) also differentiate ties with different partners, thus studying the impact of multiple networks-resulting in a separate network resource distribution for a given resource for each network. The metrics they use for the ego networks are network size-in essence, the number of ties to each different type of partner-and network efficiency, expressed in terms of a Hirschman-Herfindahl index over the different types of partners.

The resources of network partners were measured in terms of the relative scopes of competitive activity between the focal firm and its potential rivals in the biotechnology industry, as well as the innovative capabilities of network partners. These two measures represent two ways of aggregating partner resources: innovative capabilities are summed for all network partners, while the relative scope of competitive activity relates the firm's own scope to the summed scope of its potential rivals. This latter measure provides an example of a situation in which the relative resources of network firms have an impact on the focal firm performance. 


\section{Bae and Gargiulo (2004)}

The study by Bae and Gargiulo (2004) examined how alliance network structure and resources controlled by partners affect the focal firm performance. In contrast to Baum et al. (2000), they also considered explicit ties between partners and used the metric of network density to measure network structure around the focal firms, thus expanding the network metric beyond the dyadic ties between the focal firm and its immediate network partners. However, the metric used was still one-dimensional-i.e., it is dependent only on the focal firm.

In terms of partner resources, Bae and Gargiulo (2004) measured the market shares and quasi-monopoly status of immediate network partners. An index was formed for the former by summing over the market shares of partners, while for the latter the market share of partners with quasimonopoly status was used as a measure. Both of these measures are again one-dimensional for each focal firm, and accordingly, the resultant network resource distribution is also one-dimensional. However, the study of Bae and Gargiulo demonstrates that a network resource distribution does not need to be limited to the immediate partners and that distributions can account for the whole network structure beyond immediate dyadic ties.

\section{Koka and Prescott (2008)}

The study of Koka and Prescott (2008) is an example of research on alliance networks that incorporates measures of the focal firm's position within interfirm networks. The authors used network centrality and degree metrics to measure the strength of the focal firm positioning and a structural hole metric to characterize the network structure. In terms of the network resource distribution concept, they thus used one-dimensional metrics that were measured over the whole network. Moreover, their study also used a weighing scheme, in which the intensity of collaboration in each alliance was measured and used in the calculation of network metrics. This provides an example of how tie strength can be included as part of a network resource distribution.

Unlike the other two previous studies discussed above, the study by Koka and Prescott (2008) only incorporates ego resources-strategy type-in the interaction between firm resources and network structure. Apparently, this type of measure does not need to be aggregated, and the measure depends only on the focal firm. This study thus exemplifies that the concept of network resource distribution can accommodate research that does not explicitly include partner resources. 


\section{Zaheer and Bell (2005)}

The study by Zaheer and Bell (2005) related the occurrence of structural holes in interfirm networks with focal firm and partner innovativeness. Using data from the Canadian mutual fund industry, they were able to construct the structure of the entire network instead of just the immediate partners of focal firms. Using these data, they measured structural holes between the focal firm and all possible network partners, including indirectly connected partners. In terms of the network resource distribution concept, they constructed a one-dimensional metric-structural holes-that depended on the chosen focal firm.

This structural measure was then complemented with two measures of firm resources: focal firm innovativeness and partner innovativeness. Partner innovativeness was measured as a weighted average of the innovativeness of all partners, using the reciprocals of partner network redundancy as weights. This partner innovativeness measure thus captured, to some degree, how the innovativeness of partners was distributed in the network as measured from the focal firm. However, despite this weighting, the partner innovativeness measure was still an aggregate measure of partner resources. No detailed information on how innovative partners were specifically positioned with respect to the focal firm was used. Thus, the resulting network resource distribution was still only one-dimensional. Nevertheless, this study highlights the main idea behind the concept of network resource distribution: when analyzing firm performance in interfirm networks, the analysis should not be limited only to the resources of immediate partners; rather, the whole network should also be accounted for.

\section{Phelps (2010)}

The study by Phelps (2010) investigated how network density and partner knowledge diversity interact to affect the focal firm explorative innovation. Network structure was again measured in terms of network density over potential ties between the focal firm's immediate network partners, and thus, the measure extended beyond the simple dyadic level of analysis.

By contrast, Phelps (2010) measured partner knowledge diversity based on a categorization of the firms' patents and their uniqueness among the partners, calculated over the whole network. This measure thus accesses the resources of all partners in the network, including those that are only indirectly linked to the focal firm. However, the resulting measure is only onedimensional and depends only on the chosen focal firm. Combined with the network density measure, the resulting network resource distribution is again 
one-dimensional and thus depends only on the chosen focal firm. Interestingly, Phelps also considers a curvilinear relationship between network knowledge diversity and the focal firm performance. This is an example of how different types of network resource distribution measures can be related to the focal firm performance.

\section{Summary}

The selected five empirical studies highlight how existing research has considered the interaction between firm resources and interfirm network structure. However, closer analysis revealed that only a few of the potential types of interaction have thus far been examined empirically. For example, none of the studies considered the possibility of studying the individual resources of specific network partners. The studies also use a relatively unvaried set of network structure metrics and resource measures. In this sense, the generic network resource distribution concept helps to reveal which conceptually possible combinations have not yet been considered, and where contributions are still needed to improve the understanding of the interplay between the resource-based view and the social network theory. Importantly, the analysis of the selected studies also demonstrated that the existing analytical models can be conceptually deduced from the concept of network resource distribution, highlighting its generic nature and applicability across different research goals.

\section{Network resource distributions and the focal firm performance}

As demonstrated above, the concept of network resource distribution can successfully be used to model and analyze a wide variety of combinations of interactions between firm resources and network structure. In the following, it is argued that network resource distributions matter for the focal firm performance.

First, extant research combining the resource-based view and the social network theory has indicated that in a dyadic setting, the interaction between firm resources and network structure does affect the focal firm performance (Baum et al., 2000; Kale et al., 2000; Reagans \& McEvily, 2003; Rothaermel \& Boeker, 2008). Moreover, the overall structure of interfirm networks and resources distributed throughout those networks affect the performance of firms embedded in those networks (Bae \& Gargiulo, 2004; Whittington, Owen-Smith, \& Powell, 2009; Zaheer \& Bell, 2005). These studies, although limited to the dyadic level, suggest that a combination of the two perspectives is needed to explain fully the focal firm performance. 
Second, chaining this dyadic logic implies that relational benefits are likely to ripple throughout the network. The interaction between two firms benefits the focal firm not only through access to complementary resources but also by relational advantages created by unique combinations of resources as well as by potential spillover effects from the resources of the network partner. Thus, as suggested by Lavie (2006), the resources of interconnected firms affect the performance of both firms in a dyadic relationship. While, for many resources, the boundaries of firms formed by buy-or-sell decisions are clear, this is not the case for all types of resources. For example, many knowledge resources require intermediaries, if a firm is to benefit from the knowledge of other firms (Carlile, 2004; Hargadon \& Sutton, 1997). Hence, there is a need to consider the impact of more distant network alters and their resources on the performance of the focal firm. Based on Lavie's model of competitive advantage for dyadic relationships, the resources available to the immediate partners of the focal firm depend at least partly on the resources of more distant firms in the network. The same logic can be applied to the network partners beyond the immediate ones, and so on. Thus, based on this recursive logic, it can be argued that the resources accessible to the focal firm depend to some degree on the resources possessed by all firms in the interfirm network. Now, as argued by the resource-based view of interfirm alliances, having access to required complementary resources has an impact on the performance of the focal firm by, for example, allowing it to concentrate on its own core competences and mitigating the need to invest in complementary resources. Such ambidexterity through alliances has recently been studied on the alliance portfolio level and proposed to have a positive impact on the focal firm performance (Wassmer \& Madhok, 2017). The static view of interfirm network relationships thus suggests that to understand fully the performance of the focal firm, it is necessary to consider how resources are distributed throughout the entire network. This view is also corroborated by Gulati et al. (2011), who argue that network structure, relational properties of ties, and firm attributes (i.e., resources) should all be analyzed for complete treatment. A similar indirect effect on the valuecreation potential of the "operating" resources was recently explored by Wibbens (2019) in the context of the focal firm's higher-order resources. In this view, the whole network could be seen as a higher-order resource-or a dynamic capability - that does not directly affect the performance of the focal firm but does affect it indirectly by affecting the value-creation potential of the focal firm's "operating" resources. In this same vein, to account more fully for the value-creation potential of the whole network as a higher-order resource, all of its members and their relationships with one another need to be accounted for. Another recent study suggests that the competitive tensions 
and cooperative arrangements between partners affect their value-creation prospects for the focal firm (Asgari, Tandon, Singh, \& Mitchell, 2018), further implying that additional attention needs to be paid to the partner network structure to benefit from available resources.

Third, based on the theory of relational benefits, empirical evidence from other levels of analysis also suggests that the interaction between resources and network structure needs to be analyzed beyond the dyadic level of relationships. On the organizational unit level, Hansen's (2002) study of knowledge transfer between organizational units and its impact on project completion suggests that the path length between two organizational units that need to exchange knowledge has an impact on project completion time. It is thus not sufficient to know that the required knowledge is available in a network but also know where this knowledge is located and how many ties must be crossed to access this knowledge. Interpreted in the context of interfirm networks, Hansen's results suggest, as argued in this paper, that the location of network partners possessing valuable complementary resources matters for the focal firm's performance. More recently, the study by Chiambaretto, Masse, and Mirc (2019) on the impact of knowledge brokers in managing the tensions of internal coopetition suggests that trusted knowledge brokers have a pivotal role in facilitating knowledge flows between organizational units. In the context of interfirm networks, this finding suggests that direct partners with appropriate levels of resources - trust and knowledge, for examplefacilitate and mediate resource flows originating from indirect partners. This finding points to the importance of considering the resources of all firms along longer network paths. On a managerial level, Rodan and Galunic (2004) studied how knowledge heterogeneity in managers' social networks affected their performance and innovativeness. They found that managerial performance is affected not only by the knowledge of their social contacts but also by how the knowledge of these persons is related to each other. This finding indicates that to analyze the focal firm's performance within interfirm networks, it is not enough to consider the resources of the network partners; one must also consider how the resources of these partners are related to each other.

Fourth, limited direct empirical evidence also exists in support of the presented theoretical arguments relating network resource distributions to firm performance. The study by Gulati (1995a) analyzed the formation of alliances based on prior network structure and strategic interdependence (i.e., resource characteristics). The findings of the study suggest that indirect ties matter for alliance formation, hinting that firms consider these indirect ties beneficial for their performance.

In summary, both existing empirical evidence and theoretical arguments suggest that network resource distributions have an impact on firm 
performance. However, given that the focus of this paper is on developing the unifying network resource distribution concept, testing of the related theoretical argument is left for future research.

\section{DISCUSSION}

By proposing a unifying concept that accounts for the network structure and firm resources, this paper makes two contributions to research on interfirm networks. First, the network resource distribution concept systemizes the existing research on interfirm networks that has sought to combine the resource-based view and the social network theory. The concept generalizes the currently used conceptualizations of the perspectives and provides an integrated, coherent framework for future research on interfirm networks. The unifying concept highlights similarities and differences in existing research and helps authors in the area relate their work to the work of other researchers, as existing approaches can be derived deductively from the concept (c.f., Carpenter et al., 2012). Furthermore, the network resource distribution concept helps to identify gaps in the existing knowledge about the combined impact of interfirm networks and firm resources, highlighting potential avenues for future research. As research on the strategic impact of interfirm networks is still in a relatively early phase, the concept helps researchers direct their efforts to areas that are likely to enhance the understanding of the interaction between resources and network structures. Relatedly, as a step towards closing a specific and significant gap in the literature, the network resource distribution concept highlights the importance of studying the interaction between resources and network structure beyond the dyadic level. As already suggested in the existing literature (e.g., Gulati et al., 2011), the resources of indirectly related firms can also influence the focal firm performance. The concept accentuates this point by emphasizing the importance of observing the actual resources within the network beyond the immediate partners (cf. Tasselli, Kilduff, \& Menges, 2015).

Second, similar to the work of Carpenter et al. (2012), the network resource distribution concept complements prior studies and paves the way for new studies that propose complex theoretical concepts combining network position and firm resources by aiding the operationalization and, thereby, the testing of the concepts. For example, the unifying concept complements the theoretical framework of Gulati et al. (2011), aiding highprecision operationalization and testing of the proposed reach, richness, and receptivity concepts - the three mechanisms that are proposed to drive the firm-level performance outcomes of networks. 


\section{Avenues for future research}

The network resource distribution concept opens new and significant opportunities for researchers to contribute to research on interfirm networks and firm performance. The proposed concept constitutes a small step forward; many further theoretical issues need to be investigated in the future. First, how does the network configuration at the network node levelthe resource mix and the resource characteristics-affect the optimal shape of network resource distributions? Second, how do configuration choices at the relational level affect the optimal shapes of the distributions? Recent research indicates that relational factors, such as competitive tensions and cooperative arrangements among partners (Asgari et al., 2018) as well as trust (Chiambaretto et al., 2019), affect the value of partners for the focal firm. Third, how do external environmental conditions influence the optimal shapes of the distributions? Prior research indicates, for example, that the prevailing regime of intellectual property protection affects the flow of resources between firms (Dushnitky \& Shaver, 2009). Fourth, it would be interesting to study how the optimal shapes of network resource distributions depend on the configuration choices made on the whole network level and how optimal distributions evolve over time. Recent studies on alliance portfolios indicate that portfolio configuration choices play an important role in determining how much value the focal firm can derive from its network of partners over time (Andrevski, Brass, \& Ferrier, 2016: Martinez, Zouaghi, \& Garcia, 2017). Specifically, recent research indicates that the focal firm can achieve ambidexterity through alliances with an appropriate diversity of partners (Wassmer \& Madhok, 2017), that partner diversity also affects relational characteristics such as trust (Lee et al., 2017), and that resourceutilization levels are significant drivers of network evolution at the alliance portfolio level (Chiambaretto \& Wassmer, 2019). Network level configuration studies could seek to extend these findings from the alliance portfolio to the network level. The proposed network resource distribution concept could be used to test the validity of these portfolio level findings on the network level. Fifth, recent research has investigated firm exploratory and exploitative innovation output on the individual inventor level (e.g., Grigoriou \& Rothaermel, 2017; Tasselli et al., 2015; Yan \& Guan, 2018), suggesting that unpacking firm level aggregate measures into more fine-grained employee level resource networks would reveal strategically significant but otherwise invisible configurations. Interestingly, the network resource distribution concept could also be applied on the employee level to further extend these efforts. Finally, it has been argued that the social network theory needs to be extended into a multilevel theory-accounting for individuals and their 
collectives. In this vein, Paruchuri, Goossen, and Phelps (2019) have recently suggested conceptual foundations for multilevel social networks. Future research could build upon the study of Parachuri et al. (2019) and seek to investigate how network resource distributions on various levels of analysis interact with one another.

\section{Managerial implications}

Viewing an interfirm network through the network resource distribution lens highlights that managers should not limit their analyses of strategic alliances to immediate partnerships; it is also essential to consider the partners, their resources, and how they are related to one another outside of the immediate partnership sphere. Thus, managers are encouraged to shift their focus from dyadic strategic alliances towards sequential partnering, a strategy in which firms accrue value outside of immediate partnerships. To this end, the commonly practiced ego network analysis should be applied not only to the focal firm but also to every network partner to reveal the true value-added of the partners. Network synergies (Hernandez \& Shaver, 2019) can constitute a significant portion of the value-added of a partner.

\section{CONCLUSION}

Although prior research has sought to integrate the resource-based view and the social network theory perspectives on interfirm networks and their impact on firm performance, this research has been limited to the types of interactions considered between firm resources and network structure. To provide a coherent and unifying grounding for further research in the area, a unifying concept of network resource distribution-defined as the spatial pattern of resources within an interfirm network, in which a specific location is related to specific levels of those resources-is introduced. This concept combines-in detail-the concepts of network structure and firm resources and, thereby, facilitates further empirical inquiry by aiding the operationalization of related complex constructs that have, thus far, received only theoretical treatment. Based on theoretical arguments and existing empirical evidence, it is argued that network resource distributions can be linked to firm performance. 


\section{References}

Afuah, A. (2000). How much do your co-opetitors' capabilities matter in the face of technological change? Strategic Management Journal, 21(3), 397-404. https://doi.org/10.1002/(SICI)1097-0266(200003)21:3\%3C397::AIDSMJ88\%3E3.0.CO;2-1

Aggarwal, V. A. (2020). Resource congestion in alliance networks: How a firm's partners' partners influence the benefits of collaboration. Strategic Management Journal, 41(4), 627-655. https://doi.org/10.1002/ smj.3109

Ahuja, G. (2000). Collaboration networks, structural holes, and innovation: A longitudinal study. Administrative Science Quarterly, 45(3), 425-455. https://doi.org/10.2307/2667105

Andrevski, G., Brass. D., \& Ferrier, W. (2016). Alliance portfolio configurations and competitive action frequency. Journal of Management, 42(4), 811837. https://doi.org/10.1177/0149206313498901

Arya, B., \& Lin, Z. (2007). Understanding collaboration outcomes from an extended resource-based view perspective: The roles of organizational characteristics, partner attributes, and network structures. Journal of Management, 33(5), 697-723. https://doi. org $/ 10.1177 / 0149206307305561$

Asgari, N., Tandon, V., Singh, K., \& Mitchell, W. (2018). Creating and taming discord: How firms manage embedded competition in alliance portfolios to limit alliance termination. Strategic Management Journal, 39, 32733299. https://doi.org/10.1002/smj.2784

Bae, J., \& Gargiulo, M. (2004). Partner substitutability, alliance network structure, and firm profitability in the telecommunications industry. Academy of Management Journal, 47(6), 843-859. https://doi. org/10.5465/20159626

Barney, J. B. (1991). Firm resources and sustained competitive advantage. Journal of Management, 17(1), 99-120. https://doi. org/10.1177/014920639101700108

Baum, J. A. C., Calabrese, T., \& Silverman, B. S. (2000). Don't go it alone: Alliance network composition and startups' performance in Canadian biotechnology. Strategic Management Journal, 21(3), 267-294. https://doi.org/10.1002/(SICI)1097-0266(200003)21:3<267::AIDSMJ89>3.0.CO;2-8

Borgatti, S. P., \& Halgin, D. S. (2011). On network theory. Organization Science, 22(5), 1168-1181. https://doi.org/10.1287/orsc.1100.0641

Burt, R. S. (1992). Structural Holes: The Social Structure of Competition. Cambridge, MA, USA: Harvard University Press. https://doi. org/10.1177/000169939403700410

Burt, R. S. (2000). The network structure of social capital. Research in Organizational Behavior, 22, 345-423. https://doi.org/10.1016/S01913085(00)22009-1 
Burt, R. S. (2004). Structural holes and good ideas. American Journal of Sociology, 110(2), 349-399. https://doi.org/10.1086/421787

Burt, R. S., \& Soda, G. (2021). Network capabilities: Brokerage as a bridge between network theory and the resource-based view of the firm. Journal of Management, forthcoming. https://doi. org/10.1177/0149206320988764

Carlile, P. R. (2004). Transferring, translating, and transforming: An integrative framework for managing knowledge across boundaries. Organization Science, 15(5), 555-568. https://doi.org/10.1287/orsc.1040.0094

Carnabuci, G., \& Operti, E. (2013). Where do firms' recombinant capabilities come from? Intraorganizational networks, knowledge, and firms' ability to innovate through technological recombination. Strategic Management Journal, 34(13), 1591-1613. https://doi.org/10.1002/smj.2084

Carpenter, M. A., Li, M., \& Jiang, H. (2012). Social network research in organizational contexts: A systematic review of methodological issues and choices. Journal of Management, 38(4), 1328-1361. https://doi. org/10.1177/0149206312440119

Chiambaretto, P., Masse, D., \& Mirc, N. (2019). "All for One and One for All?" Knowledge broker roles in managing tensions of internal coopetition: The Ubisoft case. Research Policy, 48, 584-600. https://doi.org/10.1016/j. respol.2018.10.009

Chiambaretto, P., \& Wassmer, U. (2019). Resource utilization as an internal driver of alliance portfolio evolution: The Qatar Airways case (19932010). Long Range Planning, 52, 51-71. https://doi.org/10.1016/j. Irp.2018.02.004

Cohen, W. M., \& Levinthal, D. A. (1990). Absorptive capacity: A new perspective on learning and innovation. Administrative Science Quarterly, 35(1), 12852. https://doi.org/10.2307/2393553

Cui, A. S., \& O'Connor, G. (2012). Alliance portfolio resource diversity and firm innovation. Journal of Marketing, 76(4), 24-43. https://doi.org/10.1509/ jm.11.0130

Das, T. K., \& Teng, B. S. (2000). A resource-based theory of strategic alliances. Journal of Management, 26(1), 31-61. https://doi.org/10.1509/ jm.11.0130

Dittrich, K., \& Duysters, G. (2007). Networking as a means to strategy change: The case of open innovation in mobile telephony. Journal of Product Innovation Management, 24(6), 510-521. https://doi.org/10.1111/ j.1540-5885.2007.00268.x

Dushnitky, G., \& Shaver, J. M. (2009). Limitations to inter-organizational knowledge acquisitions: The paradox of corporate venture capital. Strategic Management Journal, 30, 1045-1064. https://doi.org/10.1002/ smj.781

Dyer, J. H., \& Hatch, N. W. (2006). Relation-specific capabilities and barriers to knowledge transfers: Creating advantage through network relationships. 
Strategic Management Journal, 27(8), 701-719. https://doi.org/10.1002/ smj.543

Dyer, J. H., \& Singh, H. (1998). The relational view: Cooperative strategy and sources of interorganizational competitive advantage. Academy of Management Review, 23(4), 660-679. https://doi.org/10.2307/259056

Eisenhardt, K. M., \& Schoonhoven, C. B. (1996). Resource-based view of strategic alliance formation: Strategic and social effects in entrepreneurial firms. Organization Science, 7(2), 136-150. https://doi.org/10.1287/ orsc.7.2.136

Galunic, D. C., \& Rodan, S. (1998). Resource recombinations in the firm: Knowledge structures and the potential for Schumpeterian innovation. Strategic Management Journal, 19(12), 1193-1201. https://doi.org/10.1002/(SICI)1097-0266(1998120)19:12<1193::AIDSMJ5>3.0.CO;2-F

Gargiulo, M., \& Benassi, M. (2000). Trapped in your own net? Network cohesion, structural holes, and the adaptation of social capital. Organization Science, 11(2), 183-196. https://doi.org/10.1287/ orsc.11.2.183.12514

Gilsing, V., Nooteboom, B., Vanhaverbeke, W., Duysters, G., \& van den Oord, A. (2008). Network embeddedness and the exploration of novel technologies: Technological distance, betweenness centrality and density. Research Policy, 37(10), 1717-1731. https://doi.org/10.1016/j. respol.2008.08.010

Grigoriou, K., \& Rothaermel, F. (2017). Organizing for knowledge creation: Internal knowledge networks and the contingent effect of external knowledge sourcing. Strategic Management Journal, 38, 395-414. https://doi.org/10.1002/smj.2489

Grant, R. M., \& Baden-Fuller, C. (2004). A knowledge accessing theory of strategic alliances. Journal of Management Studies, 41(1), 61-84. https:// doi.org/10.1111/j.1467-6486.2004.00421.x

Guan, J., \& Liu, N. (2016). Exploitative and exploratory innovations in knowledge network and collaboration network: A patent analysis in the technological field of nano-energy. Research Policy, 45(1), 97-112. https://doi.org/10.1016/j.respol.2015.08.002

Gulati, R. (1995a). Social structure and alliance formation patterns: A longitudinal analysis. Administrative Science Quarterly, 40(4), 619-652. https://doi.org/10.2307/2393756

Gulati, R. (1995b). Does familiarity breed trust? The implications of repeated ties for contractual choice in alliances. Academy of Management Journal, 38(1), 85-112. https://doi.org/10.5465/256729

Gulati, R. (1998). Alliances and networks. Strategic Management Journal, 19(4), 293-317. https://doi.org/10.1002/(SICI)10970266(199804)19:4<293::AID-SMJ982>3.0.CO;2-M

Gulati, R. (1999). Network location and learning: The influence of network resources and firm capabilities on alliance formation. Strategic 
Management Journal, 20(5), 397-420. https://doi.org/10.1002/ (SICI)1097-0266(199905)20:5<397::AID-SMJ35>3.0.CO;2-K

Gulati, R. (2007). Managing Network Resources: Alliances, Affiliations and Other Relational Assets. Oxford: Oxford University Press.

Gulati, R., \& Higgins, M. C. (2003). Which ties matter when? The contingent effects of interorganizational partnerships on IPO success. Strategic Management Journal, 24(2), 127-144. https://doi.org/10.1002/smj.287

Gulati, R., Lavie, D., \& Madhavan, R. (2011). How do networks matter? The performance effects of interorganizational networks. Research in Organizational Behavior, 31, 207-224. https://doi.org/10.1016/j. riob.2011.09.005

Gulati, R., Nohria, N., \& Zaheer, A. (2000). Strategic networks. Strategic Management Journal, 21(3), 203. https://doi.org/10.1002/(SICl)10970266(200003)21:3<203::AID-SMJ102>3.0.CO;2-K

Hagedoorn, J., Lokshin, B., \& Zobel, A-K. (2018). Partner type diversity in alliance portfolios: Multiple dimensions, boundary conditions and firm innovation performance. Journal of Management Studies, 55(5), 809-836. https://doi.org/10.1111/joms.12326

Hamel, G. (1991). Competition for competence and interpartner learning within international strategic alliances. Strategic Management Journal, 12, 83-103. https://doi.org/10.1002/smj.4250120908

Hansen, M. T. (2002). Knowledge networks: Explaining effective knowledge sharing in multiunit companies. Organization Science, 13(3), 232-248. https://doi.org/10.1287/orsc.13.3.232.2771

Hargadon, A., \& Sutton, R. I. (1997). Technology brokering and innovation in a product development firm. Administrative Science Quarterly, 42(4), 716-749. https://doi.org/10.2307/2393655

Hernandez, E., \& Shaver, J. M. (2019). Network synergy. Administrative Science Quarterly, 64(1), 171-202. https://doi.org/10.1177/0001839218761369

Howells, J. (2006). Intermediation and the role of intermediaries in innovation. Research Policy, 35(5), 715-728. https://doi.org/10.1016/j. respol.2006.03.005

Huggins, R. (2010). Forms of network resource: Knowledge access and the role of inter firm networks. International Journal of Management Reviews, 12(3), 335-352. https://doi.org/10.1111/j.1468-2370.2009.00266.x

Inkpen, A. C. (2000). Learning through joint ventures: A framework of knowledge acquisition. Journal of Management Studies, 37(7), 10191044. https://doi.org/10.1111/1467-6486.00215

Inkpen, A. C., \& Tsang, E. W. K. (2005). Social capital, networks, and knowledge transfer. Academy of Management Review, 30(1), 146-165. https://doi. org/10.2307/20159100

Jiang, R. J., Tao, Q. T., \& Santoro, M. D. (2010). Alliance portfolio diversity and firm performance. Strategic Management Journal, 31(10), 1136-1144. https://doi.org/10.1002/smj.869 
Kale, P., Dyer, J. H., \& Singh, H. (2002). Alliance capability, stock market response, and long-term alliance success: The role of the alliance function. Strategic Management Journal, 23(8), 747-767. https://doi. org $/ 10.1002 / \mathrm{smj} .248$

Kale, P., Singh, H., \& Perlmutter, H. (2000). Learning and protection of proprietary assets in strategic alliances: Building relational capital. Strategic Management Journal, 21(3), 217-237. https://doi.org/10.1002/ (SICI)1097-0266(200003)21:3<217::AID-SMJ95>3.0.CO;2-Y

Koka, B. R., \& Prescott, J. E. (2002). Strategic alliances as social capital: A multidimensional view. Strategic Management Journal, 23(9), 795816. https://doi.org/10.1002/smj.252

Koka, B. R., \& Prescott, J. E. (2008). Designing alliance networks: The influence of network position, environmental change, and strategy on firm performance. Strategic Management Journal, 29(6), 639-661. https:// doi.org/10.1002/smj.679

Kraatz, M. S. (1998). Learning by association? Interorganizational networks and adaptation to environmental change. Academy of Management Journal, 41(6), 621-643. https://doi.org/10.5465/256961

Krishnan, R., Martin, X., \& Noorderhaven, N. G. (2006). When does trust matter to alliance performance? Academy of Management Journal, 49(5), 894-917. https://doi.org/10.5465/amj.2006.22798171

Kwon, S.-W., Rondi, E., Levin, D. Z., De Massis, A., \& Brass, D. J. (2020). Network brokerage: An integrative review and future research agenda. Journal of Management, 46(6), 1092-1120. https://doi. org/10.1177/0149206320914694

Lado, A. A., Boyd, N. G., \& Hanlon, S. C. (1997). Competition, cooperation, and the search for economic rents: A syncretic model. Academy of Management Review, 22(1), 110-141. https://doi.org/10.2307/259226

Lane, P. J., \& Lubatkin, M. (1998). Relative absorptive capacity and interorganizational learning. Strategic Management Journal, 19(5), 461477. https://doi.org/10.1002/(SICI)1097-0266(199805)19:5<461::AIDSMJ953>3.0.CO;2-L

Lavie, D. (2006). The competitive advantage of interconnected firms: An extension of the resource-based view. Academy of Management Review, 31(3), 638-658. https://doi.org/10.2307/20159233

Lavie, D. (2007). Alliance portfolios and firm performance: A study of value creation and appropriation in the US software industry. Strategic Management Journal, 28(12), 1187-1212. https://doi.org/10.1002/ smj.637

Lee,D., Kirkpatrick-Husk,K.,\&Madhavan, R. (2017).Diversityinallianceportfolios and performance outcomes: A meta-analysis. Journal of Management, 43(5), 1472-1497. https://doi.org/10.1177/0149206314556316

Lin, C., Wu, Y-J., Chang, C., Wang, W., \& Lee, C-Y. (2012). The alliance innovation performance of R\&D alliances-the absorptive 
capacity perspective. Technovation, 32(5), 282-292. https://doi. org/10.1016/j.technovation.2012.01.004

Madhok, A., \& Tallman, S. B. (1998). Resources, transactions and rents: Managing value through interfirm collaborative relationships. Organization Science, 9(3), 326-339. https://doi.org/10.1287/orsc.9.3.326

Martinez, M., Zouaghi, F., \& Garcia, S. (2017). Capturing value from alliance portfolio diversity: The mediating role of R\&D human capital in high and low tech industries. Technovation, 59, 55-67. https://doi.org/10.1016/j. technovation.2016.06.003

McEvily, B., \& Marcus, A. (2005). Embedded ties and the acquisition of competitive capabilities. Strategic Management Journal, 26(11), 10331055. https://doi.org/10.1002/smj.484

Mesquita, L. F., Anand, J., \& Brush, T. H. (2008). Comparing the resourcebased and relational views: Knowledge transfer and spillover in vertical alliances. Strategic Management Journal, 29(9), 913-941. https://doi. org/10.1002/smj.699

Monaghan, S., Lavelle, J., \& Gunnigle, P. (2017). Mapping networks: Exploring the utility of social network analysis in management research and practice. Journal of Business Research, 76, 136-144. https://doi. org/10.1016/j.jbusres.2017.03.020

Mowery, D. C., Oxley, J. E., \& Silverman, B. S. (1996). Strategic alliances and interfirm knowledge transfer. Strategic Management Journal, 17, 77-91. https://doi.org/10.1002/smj.4250171108

Nahapiet, J., \& Ghoshal, S. (1998). Social capital, intellectual capital, and the organizational advantage. Academy of Management Review, 23(2), 242266. https://doi.org/10.2307/259373

Owen-Smith, J., \& Powell, W. W. (2004). Knowledge networks as channels and conduits: The effects of spillovers in the Boston biotechnology community. Organization Science, 15(1), 5-21. https://doi.org/10.1287/ orsc.1030.0054

Parachuri, S., Goosen, M., \& Phelps, C. (2019). Conceptual foundations of multilevel social networks. In S. E. Humphrey \& J. M. LeBreton (Eds.), The Handbook of Multilevel Theory, Measurement, and Analysis (pp. 201221). Washington, DC: American Psychological Association. https://doi. org/10.1037/0000115-010

Peteraf, M. A. (1993). The cornerstones of competitive advantage: A resourcebased view. Strategic Management Journal, 14(3), 179-191. https://doi. org/10.1002/smj.4250140303

Phelps, C. (2010). A longitudinal study of the influence of alliance network structure and composition on firm exploratory innovation. Academy of Management Journal, 53(4), 890-913. https://doi.org/10.5465/ amj.2010.52814627

Phelps, C., Heidl,R., \&Wadhwa, A. (2012). Knowledge, networks, and knowledge networks: A review and research agenda. Journal of Management, 38(4), 1115-1166. https://doi.org/10.1177/0149206311432640 
Polidoro, F., Ahuja, G., \& Mitchell, W. (2011). When the social structure overshadows competitive incentives: the effects of network embeddedness on joint venture dissolution. Academy of Management Journal, 54(2), 369-392. https://doi.org/10.5465/amj.2011.59215088

Powell, W. W., Koput, K. W., \& Smith-Doerr, L. (1996). Interorganizational collaboration and the locus of innovation: Networks of learning in biotechnology. Administrative Science Quarterly, 41(1), 116-145. https:// doi.org/10.2307/2393988

Prahalad, C. K., \& Hamel, G. (1990). The core competence of the corporation. Harvard Business Review, 68(3), 79-91.

Reagans, R., \& McEvily, B. (2003). Network structure and knowledge transfer: The effects of cohesion and range. Administrative Science Quarterly, 48(2), 240-267. https://doi.org/10.2307/3556658

Rodan, S., \& Galunic, C. (2004). More than network structure: How knowledge heterogeneity influences managerial performance and innovativeness. Strategic Management Journal, 25(6), 541-562. https://doi.org/10.1002/ smj.398

Rothaermel, F. T., \& Boeker, W. (2008). Old technology meets new technology: Complementarities, similarities, and alliance formation. Strategic Management Journal, 29(1), 47-77. https://doi.org/10.1002/smj.634

Rothaermel, F. T., \& Deeds, D. L. (2006). Alliance type, alliance experience and alliance management capability in high-technology ventures. Journal of Business Venturing, 21(4), 429-460. https://doi.org/10.1016/j. jbusvent.2005.02.006

Rulke, D. L., \& Galaskiewicz, J. (2000). Distribution of knowledge, group network structure, and group performance. Management Science, 46(5), 612-625. https://doi.org/10.1287/mnsc.46.5.612.12052

Schilling, M. A. (2009). Understanding the alliance data. Strategic Management Journal, 30, 233-260. https://doi.org/10.1002/smj.731

Schilling, M. A., \& Phelps, C. C. (2007). Interfirm collaboration networks: The impact of large-scale network structure on firm innovation. Management Science, 53(7), 1113-1126. https://doi.org/10.1287/mnsc.1060.0624

Shan, W., Walker, G., \& Kogut, B. (1994). Interfirm cooperation and startup innovation in the biotechnology industry. Strategic Management Journal, 15(5), 387-394. https://doi.org/10.1002/smj.4250150505

Shohet, S., \& Prevezer, M. (1996). UK biotechnology: Institutional linkages, technology transfer and the role of intermediaries. R\&D Management, 26, 283-298. https://doi.org/10.1111/j.1467-9310.1996.tb00962.x

Simonin, B. L. (2004). An empirical investigation of the process of knowledge transfer in international strategic alliances. Journal of International Business Studies, 35(5), 407-427. https://doi.org/10.1057/palgrave. jibs. 8400091

Soh, P. (2010). Network patterns and competitive advantage before the emergence of a dominant design. Strategic Management Journal, 31(4), 438-461. https://doi.org/10.1002/smj.819 
Subramanian, A., \& Soh, P. (2017). Linking alliance portfolios to recombinant innovation: The combined effects of diversity and alliance experience. Long Range Planning, 50(5), 636-652. https://doi. org/10.1016/j.Irp.2016.11.001

Subramanian, A., Bo, W., \& Kah-Hin, C. (2018). The role of knowledge base homogeneity in learning from strategic alliances. Research Policy, 47: 158-168. https://doi.org/10.1016/j.respol.2017.10.005

Stuart, T. E. (1998). Network positions and propensities to collaborate: An investigation of strategic alliance formation in a high-technology industry. Administrative Science Quarterly, 43(3), 668-698. https://doi. org/10.2307/2393679

Stuart, T. E. (2000). Interorganizational alliances and the performance of firms: A study of growth and innovation rates in a high-technology industry. Strategic Management Journal, 21(8), 791-811. https://doi. org/10.1002/1097-0266(200008)21:8<791::AID-SMJ121>3.0.CO;2-K

Tasselli, S., Kilduff, M., \& Menges, J. (2015). The microfoundations of organizational social networks: A review and an agenda for future research. Journal of Management, 41(5), 1361-1387. https://doi. org/10.1177/0149206315573996

Teece, D. J. (1986). Profiting from technological innovation: Implications for integration, collaboration, licensing and public policy. Research Policy, 15(6), 285-305. https://doi.org/10.1016/0048-7333(86)90027-2

Teece, D. J., Pisano, G., \& Shuen, A. (1997). Dynamic capabilities and strategic management. Strategic Management Journal, 18(7), 509533. https://doi.org/10.1002/(SICI)1097-0266(199708)18:7<509::AIDSMJ882>3.0.CO;2-Z

Tsai, W. (2001). Knowledge transfer in intraorganizational networks: Effects of network position and absorptive capacity on business unit innovation and performance. Academy of Management Journal, 44(5), 996-1004. https://doi.org/10.5465/3069443

Tsai, W., \& Ghoshal, S. (1998) Social capital and value creation: The role of intrafirm networks. Academy of Management Journal, 41(4), 464-476. https://doi.org/10.5465/257085

Uzzi, B. (1996). The sources and consequences of embeddedness for the economic performance of organizations: The network effect. American Sociological Review, 61, 674-698. https://doi.org/10.2307/2096399

Uzzi, B. (1997). Social structure and competition in interfirm networks: The paradox of embeddedness. Administrative Science Quarterly, 42(1), 3567. https://doi.org/10.2307/2393808

Vasudeva, G., Zaheer, A., \& Hernandez, E. (2013). The embeddedness of networks: Institutions, structural holes, and innovativeness in the fuel cell industry. Organization Science, 24(3), 645-663. https://doi.org/10.1287/ orsc. 1120.0780 
Walker, G., Kogut, B., \& Shan, W. (1997). Social capital, structural holes and the formation of an industry network. Organization Science, 8(2), 109125. https://doi.org/10.1287/orsc.8.2.109

Wang, L., \& Zajac, E. J. (2007). Alliance or acquisition? A dyadic perspective on interfirm resource combinations. Strategic Management Journal, 28(13), 1291-1317. https://doi.org/10.1002/smj.638

Wang, C., Rodan, S., Fruin, M., \& Xu, X. (2014). Knowledge networks, collaboration networks, and exploratory innovation. Academy of Management Journal, 57(2), 484-514. https://doi.org/10.5465/ amj.2011.0917

Wassmer, U. (2010). Alliance portfolios: A review and research agenda. Journal of Management, 36(1), 141-171. https://doi. org/10.1177/0149206308328484

Wassmer, U., Li, S., \& Madhok, A. (2017). Resource ambidexterity through alliance portfolios and firm performance. Strategic Management Journal, 38(2), 384-394. https://doi.org/10.1002/smj.2488

Wernerfelt, B. (1984). A resource-based view of the firm. Strategic Management Journal, 5(2), 171-180. https://doi.org/10.1002/ smj.4250050207

Whittington, K., Owen-Smith, J., \& Powell, W. (2009). Networks, propinquity, and innovation in knowledge-intensive industries. Administrative Science Quarterly, 54(1), 90-122. https://doi.org/10.2189/asqu.2009.54.1.90

Wibbens, P. (2019). Performance persistence in the presence of higher-order resources. Strategic Management Journal, 40, 181-202. https://doi. org/10.1002/smj.2979

Wiklund, J., \& Shepherd, D. A. (2008). The effectiveness of alliances and acquisitions: The role of resource combination activities. Entrepreneurship Theory and Practice, 33(1), 193-212. https://doi.org/10.1111/j.15406520.2008.00286.x

Wuyts, S., \& Dutta, S. (2014). Benefiting from alliance portfolio diversity: The role of past internal knowledge creation strategy. Journal of Management, 40(6), 1653-1674. https://doi.org/10.1177/0149206312442339

Yan, Y., \& Guan, J. (2018). Social capital, exploitative and exploratory innovations: The mediating roles of ego-network dynamics. Technological Forecasting and Social Change, 126, 244-258. https://doi.org/10.1016/j. techfore.2017.09.004

Zaheer, A., \& Bell, G. G. (2005). Benefiting from network position: Firm capabilities, structural holes, and performance. Strategic Management Journal, 26(9), 809-825. https://doi.org/10.1002/smj.482

Zaheer, A., Gözübüyük, R. \& Milanov, H. (2010). It's the connections: The network perspective in interorganizational research. Academy of Management Perspectives, 24(1), 62-77. https://doi.org/10.5465/ amp.24.1.62 
Abstrakt
CEL: Celem tego artykułu jest zaproponowanie koncepcji dystrybucji zasobów siecio-
wych, która systematycznie ujednolica zasobowq i sieciowq perspektywę sieci mię-
dzyorganizacyjnych oraz umożliwia zintegrowanq analizę interakcji zasobów firmy
i struktury sieci w celu wpływania na wydajność firmy. METODYKA: Zawiera prze-
glad istniejqcej literatury na temat sieci międzyorganizacyjnych, a następnie rozwija
ujednoliconq koncepcję dystrybucji zasobów sieciowych. WYNIKI: Przeglad literatu-
ry wskazuje, że badacze strategii od dawna starali się zintegrować poglqd oparty
na zasobach i wynikach firmy w sieciach społecznych, ale jak dotqd osiqgnięto tylko
częściowq integrację. W szczególności badania nad heterogenicznościq na poziomie
zasobów sieci międzyorganizacyjnych ograniczyły się w dużej mierze do analizy diad
firm. W jaki sposób zasoby firmy i struktura sieci poza bezpośrednimi partnerami
sieci współdziałajq, aby wpływać na wyniki firmy, nie zostało jeszcze odpowiednio
wyjaśnione. Zaproponowana ujednolicona koncepcja dystrybucji zasobów sieciowych
systematyzuje wcześniejsze badania i wyjaśnia, w jaki sposób struktura sieci i zaso-
by firmy oddziałujq, wpływajqc na wydajność firmy poza bezpośrednimi partnerami
sieci. IMPLIKACJE DLA TEORII I PRAKTYKI: Niniejszy artykuł zwraca uwagę na luki
wistniejqcej literaturze na temat sieci międzyorganizacyjnych i proponuje ujednolico-
nq koncepcję, którq można wykorzystać, aby zajqć się lukami badawczymi i rozwijać
dalszq teorię w tej dziedzinie. W praktyce niniejszy artykuł zachęca menedżerów, aby
nie ograniczali swoich analiz strategicznych sojuszy do bezpośrednich partnerstw;
ważne jest również, aby wziqć pod uwagę partnerów i ich zasoby oraz zastanowić się,
w jaki sposób sq ze sobq powiqzani poza bezpośrednim portfolio partnerstwa. ORY-
GINALNOSc I WARTOSc: Dystybucja zasobów sieciowych to nowatorska koncepcja, GINALNOŚĆ I WARTOŚĆ: Dystrybucja zasobów sieciowych to nowatorska koncepcja, która łączy i systematyzuje różne wątki badań nad sieciami międzyorganizacyjnymi, stanowiq̨ $w$ ten sposób podstawę dla przyszłych badań w tej dziedzinie. Koncepcja jest również podatna na szczegółowq operacjonalizację, ułatwiajq̨ późniejsze ilościowe testowanie argumentów teoretycznych łączq̨cych zasoby firmy i strukturę sieci.

Słowa kluczowe: podejście zasobowe, sieci strategiczne, relacje międzyorganizacyjne, sojusze, wydajność firmy

\section{Biographical notes}

Jesse Karjalainen, D.Sc. (Tech.), is a researcher of strategic management and technology entrepreneurship. He holds a doctor of science degree from Aalto University School of Science, Department of Industrial Engineering and Management, Finland. In addition, he holds master's degrees in economics and business administration from Aalto University School of Business, Finland, and in technology from Helsinki University of Technology, Finland. The majority of the research related to this article was conducted while Dr. Karjalainen was a researcher at Aalto University School of Science. He has also published in Business Horizons and presented his research at numerous conferences. 
Aku Valtakoski, Ph.D., is a senior lecturer in business administration at the Department of Management and Engineering at Linköping University. His research interests include understanding the role of services in manufacturing industries and knowledge-based explanations of firm performance, innovation, and industry evolution. His research has appeared in Industrial Marketing Management, Journal of Service Management, and International Journal of Operations and Production Management.

Ilkka Kauranen, D.Sc. (Tech.), is professor emeritus of Development and Management in Industry at Aalto University, Department of Industrial Engineering and Management, Finland. He is also distinguished adjunct professor at Asian Institute of Technology, Thailand. Professor Kauranen's research and teaching activities focus on entrepreneurship, development of innovations, research and development management, and co-engaging production. He has published over one hundred academic peer-reviewed journal articles, international conference papers, books, and other academic research reports. In addition to his academic career, Professor Kauranen has vast experience in top management of companies and in management consulting. At the moment, he is serving as senior vice president of Forsante Ltd, which is an information technology company in the health care sector.

\section{Conflicts of interest}

The authors declare no conflict of interest.

\section{Citation}

Karjalainen, J., Valtakoski, A., \& Kauranen, I. (2021). Interfirm network structure and firm resources: Towards a unifying concept. Journal of Entrepreneurship, Management and Innovation, 17(3), 227-264. https://doi. org/10.7341/20211737 